Pobrane z czasopisma Wschód Europy http://journals.umcs.pl/we

Data: 26/04/2023 06:14:02

DOI:10.17951/we.2020.6.1.113-133 $\quad$ Wschód Europy • Восток Европы • East of Europe vol 6, 1 / 2020

Роман Савенков

ORCID ID: https://orcid.org/0000-0002-1643-2444

Воронежский государственный университет, Россия

\title{
Протестное поведение и действие в современной России: возможности и ограничения
}

\section{Цель исследования и методология}

Целью наших наблюдений является анализ протестной активности россиян в 2010-е гг., а также оценка динамики возможностей и ограничений для публичного действия в указанный период. В рамках социологии общественных движений сложились классические традиции анализа социального и политического протеста: социально-психологические концепции коллективного поведения и относительной депривации; теории мобилизации ресурсов и политических возможностей; ценностно-ориентированный подход «новых общественных движений» ${ }^{1}$. В самом общем виде протест представляет собой «выступления граждан, направленные против действий/бездействия центральных или местных властей, содержащие критику и требования в адрес официальных лиц и институтов» ${ }^{2}$.

Под протестным поведением мы будем понимать ситуативную активность граждан, вызванную сбоем функционирования органов социального управления. Побудительным мотивом активности становятся накопленное социальное напряжение, недовольство, разочарование, рост агрессивности, спровоцированные, как правило, каким-либо шокирующим (часто трагическим) событием³. Протестное действие характеризуется рациональностью его субъектов, их способностью планировать действия и использовать разнообразные ресурсы для повышения его эффективности. «Протест возникает тогда, когда формируются

1 В. Костюшев, Социальный протест в поле политики: потенциал, репертуар, дискурс (опьт теоретической интерпретации и эмпирической верификации), „Политические исследования", 2011, № 4, с. 144.

2 Ю. Латов, Призрак «революционной ситуации»: протестные действия и протестные настроения современных россиян, „Общественные науки и современность”, 2017, № 2, с. 36.

3 См. Дж. Коэн, Э. Арато, Гражданское общество и политическая теория, Москва, 2003, с. 640. 
экономические, политические и организационные возможности, способствующие мобилизации существующего недовольства. Эти возможности превращаются в ресурсы движения» ${ }^{4}$. По мнению Ч. Тилли, даже резкое снижение уровня жизни не вызывает коллективного действия без появления новых политических возможностей. Политические возможности на макроуровне определяют тип массовой мобилизации, тип коллективных действий с соответствующим репертуаром возможных акций протеста. Структура политических возможностей определяется:

- в доминирующих социальных нормах по отношению к приемлемым формам коллективных действий. Шансы общественного действия на успех возрастают, если оно апеллирует к нормам, широко распространенным в обществе. Оценку отношения к коллективному действию мы проанализируем на основе национальных социологических опросов ${ }^{5}$. На материалах социологических исследований проведен анализ отношения россиян к такому виду взаимодействия с властью, как индивидуальный или коллективный протест, а также анализ динамики индикатора протестного потенциала;

- в правовых нормах, регулирующих взаимодействие между государственными структурами и группами интересов. Правовое регулирование определяет, насколько вероятно появление коллективного действия, каков будет доминирующий тип возникающего движения. Юридически закрепленные нормы определяют диапазон реагирования политических институтов на требования общественности, обеспечивают возможность перевода этих требований на язык официальной политики. Нами проведена оценка изменений в федеральном законодательстве, регулирующем проведение публичных акций, а также планируемые новации;

- в вероятности столкновения или кооперации интересов разных общественных движений в конкретной политической системе.

С. Тэрроу предложил включать в структуру политических возможностей только те характеристики политического режима, которые реально могут использоваться движениями для достижения целей и мобилизации поддержки. Американский социолог выделяет четыре группы показателей структуры политических возможностей: 1) степень открытости политической системы для новых акторов; 2) свидетельства переструктурирования политических сил; 3) наличие союзников движения в рамках политической системы; 4) появляющиеся расколы внутри элиты ${ }^{6}$. С. Ушкин дополняет пятый элемент политических воз-

4 Е. Здравомыслова, Парадигмы западной соииологии общественных движений, Санкт-Петербург, 1993, с. 58-59, 61.

5 Всероссийский центр изучения общественного мнения (ВЦИОМ) и Левада-Центр являются основными федеральными социологическими службами.

6 S. G. Tarrow, Power in Movement. Social Movement and Contentious Politics, Cambridge University Press, 2011, p. 154-157. 
можностей - степень подавления государством инакомыслия ${ }^{7}$. Е. Здравомыслова обращает внимание на то, что возможности возникновения коллективного поведения и действия могут быть расширены так называемыми ситуативными или случайными факторами. Их влияние сказывается во внезапном подъеме недовольства населения ${ }^{8}$.

Итак, наши наблюдения строятся на: 1) определении этапов протестного действия и анализе динамики количества и формы протестных акций; 2) на оценке общероссийского уровня социальной напряженности и протестного потенциала граждан; 3) на оценке политико-правовых возможностей и ограничений протестного действия.

\section{Этапы протестного действия}

В динамике протестного поведения и действия в России в 2008-2019 годах можно выделить следующие этапы:

I этап - 2008-2011 года: редкие общероссийские акции с неполитическими требованиями по решению конкретных проблем, рост числа трудовых протестов и стабилизация их количества;

II этап - 2011-2012 года: «Движение за честные выборы» в крупных городах страны, создание Координационного совета оппозиции, затухание движения;

III этап - 2013-2016 года: рост числа трудовых протестов, протест «дальнобойщиков» и кубанских фермеров;

IV этап - 2017-2019 года: движение сторонников А. Навального, протесты против пенсионной реформы, протесты жителей Москвы против отказа в регистрации кандидатов в депутаты Московской городской Думы и «дела Голунова».

На протяжении 2000-х годов протестная активность россиян не была масштабной и сохраняла колебательную динамику развития ${ }^{9}$. Наиболее многочисленными, охватившими разные населенные пункты, стали коллективные действия пенсионеров против «монетизации» льгот в 2005 г., а также акции в защиту Олега Щербинского, признанного виновным в дорожно-транспортном происшествии, в результате которого погиб губернатор Алтайского края Михаил Евдокимов в 2005-2006 гг. В основе названных коллективных акций лежало эмоциональное недовольство и неудовлетворенность действиями властей. Однако протестные акции были хорошо организованы, протестующие согласовывали свои мероприятия на межрегиональном уровне, рационально оценивая положительные возможности влияния масштабности протеста.

По наблюдениям политологов, уже в этот период меняется тематика протеста: коллективные действия демонстрировали не только экономическую неудов-

7 С. Ушкин, На пути к лучшему обществу, или почему люди становятся активистами, „Мониторинг общественного мнения", 2016, № 4, с. 40.

8 Е. Здравомыслова, Парадигмы западной соииологии общественных движений, Санкт-Петербург, 1993, с. 79-80.

9 G. Robertson, The Politics of Protest in Hybrid Regimes. Managing Dissent in Post-Communist Russia, Cambridge University Press, 2011, 303 p. 
летворенность участников, но и артикулировали морально-этические, правовые, экологические и политические проблемы граждан. Протестующие начали требовать установления справедливых «правил игры», то есть формирования правопорядка, универсального для всех граждан ${ }^{10}$. Стихийное агрессивное выступление футбольных болельщиков «Спартака» в Москве в декабре 2010 г. было вызвано не сколько убийством Е. Свиридова в драке с выходцами из Кавказа, сколько действиями правоохранительных органов, которые покрывали подозреваемых в преступлении. Громкими стали трудовые конфликты на автозаводах во Всеволжске и Москве (2007), во Владивостоке и моногородах (2009 г.), в Калининграде $(2010 \text { г. })^{11}$. Продолжительной по времени стала борьба общественных организаций за сохранение Химкинского леса (2007-2010 гг.). Основным видом коллективного действия в этот период были массовые митинги, блокирование путей сообщения и забастовки на предприятиях.

Протестные действия 2008-2011 гг. на уровне дискурса сохраняли неполитический характер, который приобретал политический контекст, т.к. недовольство все чаще было связано с проблемами неэффективности государственных институтов, несправедливым законодательством, произволом чиновников и коррумпированностью власти. Резонансные протестные акции вынуждали власти идти на уступки, однако множество локальных протестных действий не меняли характера взаимодействия общества и государства.

Второй этап начинается мощной волной массовых протестов в крупных городах России в конце 2011 г., которую спровоцировали массовые сообщения о нарушениях при подсчете голосов на выборах депутатов Государственной Думы 4 декабря. По подсчетам организаторов, в коллективных действиях приняли участие более ста тысяч человек. Требования пересчета голосов и отставки главы центральной избирательной комиссии в 2011 году сменились требованиями перевыборов депутатов и отставки В. Путина - в 2012 году ${ }^{12}$.

Масштабные акции коллективного действия 10 и 24 декабря в Москве показали, что граждане и власть способны в цивилизованной форме, без насилия и агрессии, взаимодействовать через коллективные публичные акции ${ }^{13}$. Оформившееся движение «За честные выборы» обозначило смещение интереса граждан с личного пространства на защиту общественных интересов. Эти протесты, в отличие от предыдущего периода, обращались не к защите партикулярных интересов, а актуализировали гражданский запрос на политическую демократию

10 С. Шкель, М. Сабитов, Массовый политический протест в современной России: динамика и специфика развития, „Право и политика”, № 10, 2012, с. 1669.

11 П. Бизюков, Динамика трудовых протестов в России (2008-2011), „Вестник общественного мнения", 2011, № 2, с. 33-34.

12 Д. Волков, Протестные митинги в России кониа 2011 - начала 2012 г2.: запрос на демократизацию политических институтов, „Вестник общественного мнения”, 2012, № 2, с. 73.

13 Доклад о состоянии гражданского общества в Российской Федерации (2011 г.), Москва, 2012, c. 6. 
и честные электоральные процедуры, породив ряд метафор о «пробуждении гражданского сознания». По своему масштабу это было одним из самых крупных движений в современной России, что позволило сравнивать его со временами перестройки или говорить о том, что «политика вернулась в Россию» ${ }^{14}$.

Всплеск митинговой активности по политическим вопросам в 2011-2012 гг. затронул лишь столицу и крупные города, но не получил поддержки большинства граждан ${ }^{15}$ : по подсчетам российских социологов, в протестных акциях приняло участие не более $4 \%$ россиян $^{16}$. По наблюдениям Л. Шевцовой, субъектом протестного действия стала не политическая (профессиональная) оппозиция, a «рассерженные горожане» - аморфная социальная общность, включающая не только представителей среднего класса городов ${ }^{17}$. По наблюдениям социологов, среди участников коллективного (на первом этапе) действия (10 декабря 2011 г.) преобладала молодежь, однако в акциях 24 декабря 2011 г., 4 февраля 2012 г. большинство составляли люди среднего возраста ${ }^{18}$.

Коллективные действия «рассерженных горожан» 2011-2012 гг. оказали двойственное влияние на политическую систему. С одной стороны, протестные акции в столице были оценены властью как сбой сложившихся к тому моменту в России политических и электоральных практик, что привело к кадровым перестановкам в Администрации Президента России. С 27 декабря 2011 года первым заместителем руководителя Администрации Президента РФ («куратором внутренней политики» в России) назначен Вячеслав Володин. В течение следующих четырех лет Кремль в целом сформировал новое качество дизайна политической системы ${ }^{19}$. На первый взгляд, были созданы дополнительные институциональные возможности для коммуникации граждан с властью, а также электорального влияния гражданского общества на политические решения: изменены правила избрания глав администраций субъектов Федерации, упрощена процедура регистрации политических партий (правом выдвигать кандидатов обладали 75 политических партий), 14 квалифицированных партий могли уча-

14 О. Лобанова, От обывателей к активистам - и обратно. Обзор протестных исследований в России 1991-2015 годов, „Неприкосновенный запас. Дебаты о политике и культуре”, 2015, № 5 , с. 28-29.

15 Например, см. Л. Шевцова, Мь: жизнь в эпоху безвременья, Москва, 2014, с. 121, Россия удивляет: пять эпох в российском общественном мнении (1987-2017). Пресс-выпуск № 3320, Всероссийский центр изучения общественного мнения, https://wciom.ru/index. php?id=236\&uid=116098, S. Greene, Moscow in Movement: Power and Opposition in Putin's Russia, Stanford University Press, 2014, 276 p.

16 Ю. Латов, Призрак «революиионной ситуации»: протестные действия и протестные настроения современных россиян, „Общественные науки и современность”, 2017, № 2, с. 39.

17 Л. Шевцова, Мы: жизнь в эпоху безвременья, Москва, 2014, с. 123-125.

18 Д. Волков, Протестные митинги в России кония 2011 - начала 2012 г2.: запрос на демократизацию политических институтов, „Вестник общественного мнения”, 2012, № 2, с. 73.

19 Развитие институтов и накопление качества. Российская политическая система между федеральными выборами 2011 и 2016 года, Re Thinking Russia, 2016, с. 5. 
ствовать в выборах депутатов Государственной Думы 2016 г. без сбора подписей, возвращена смешанная система её формирования, понижен проходной барьер в нижнюю палату Федерального парламента с 7\% до 5\%. В марте 2016 года объявлено о новом составе Центральной избирательной комиссии РФ, председателем которой была избрана Элла Памфилова, в прошлом председатель Совета при Президенте РФ по содействию развитию институтов гражданского общества и правам человека.

С другой стороны, приобретенный опыт организованного коллективного действия не изменил характера коммуникации власти и общества: власть реагировала на локальные проблемы граждан, блокируя требования системных преобразований. Политическое структурирование системных требований движения «За честные выборы» произошло лишь на нисходящей фазе протеста 12 июня 2012 г., когда была предложена программа политических преобразований «Манифест Свободной России». Осенью 2012 г. организаторы протеста создали свой координирующий орган - Координационный совет оппозиции, члены которого не смогли выработать единой привлекательной для массовых слоев общества программы действий. По мнению Л. Шевцовой, новации в избирательном и партийном законодательстве имели целью лишь успокоить «рассерженных горожан» перед церемонией инаугурации В. Путина в мае 2012 г., поощряли борьбу между политическими новичками и не устраняли монопольный характер власти ${ }^{20}$. В итоге протестные действия «За честные выборы» не стали инструментом преобразования политической системы, т.к. вопрос о глубоких институциональных реформах по инициативе общества был исключен из политической повестки дня на несколько лет ${ }^{21}$.

На третьем этапе политическая протестная активность снижается (с конца 2012), среди массовых мероприятий наиболее многочисленными становятся общероссийские провластные мероприятия и акции патриотической направленности, сосредоточенные в основном в Москве. Протестная активность в 2013-2015 гг. также концентрировалась в обеих столицах (Москва и Санкт-Петербург), практически не проявляясь в регионах. Немногочисленные акции проводились в интересах обманутых дольщиков/вкладчиков, недовольных повышением стоимости услуг жилищно-коммунальной сферы ${ }^{22}$.

В то же время, по данным Центра социально-трудовых прав увеличивается количество локальных трудовых протестов с 277 (2013 г.) до 419 в 2016 г. С отраслевой точки зрения лидерами протестной активности с 2013 г. остаются промышленность, транспорт и связь. Основной постоянной причиной протестов

20 Л. Шевцова, Мы: жизнь в эпоху безвременья, Москва, 2014, с. 125, 143.

${ }_{21}$ Г. Явлинский, Периферийный авторитаризм. Как и куда пришла Россия, Москва, 2015, с. 23.

22 Год санкиий и дешевой нефти: протестная ситуация, Центр экономических и политических peформ, http://cepr.su/wp-content/uploads/2015/11/Год-санкций-и-дешевой-нефти_протестная-ситуация1.pdf, 01.11.2018. 
является невыплата зарплаты $(57 \%)^{23}$. Структура форм, в которых происходили трудовые протесты, практически не меняется: на первом месте это выдвижение требований с угрозой последующего ужесточения протеста (53\% от общего числа акций), на втором месте подача демонстративной жалобы в органы власти (37\%), далее идут митинги (34\%) и остановка работы $(34 \%)^{24}$. Протестное поведение в этот период рассматривается Анной Очкиной как реакция граждан на различные формы нарушения их социально-трудовых прав, симптом несовершенства социально-экономической политики, недовольства государственной политикой. Экономический кризис способствовал росту локальных протестных акций, но не привел к консолидации протестных групп. Наблюдалось согласование действий протестующих на уровне муниципального образования, но взаимодействия на уровне экономического сектора или макро-региона не зафиксировано. Протестные действия с политическими требованиями не имели массовой поддержки, основывались на мобилизации отдельных активистов ${ }^{25}$.

Неожиданными для власти стало общероссийское протестное движение водителей крупнотоннажных грузовиков «Антиплатон» (ноябрь 2015 г.) и марш на Москву краснодарских фермеров на тракторах (август 2016 г.).

Система «ПлаТон» предусматривала взимание дополнительных платежей с владельцев транспортных средств, максимальная масса которых превышала 12 тонн. Персональным объектом критики стал российский бизнесмен Аркадий Ротенберг - основной выгодополучатель системы «ПлаТон». Водители и перевозчики выступили против новации по всей стране, проведя «чувствительную» для участников дорожного движения акцию «Улитка» (медленное движение на федеральных трассах). Протестующие публиковали видео-обращения к Президенту России В. Путину с просьбой отменить «ПлаТон». В регионах с протестующими дальнобойщиками встречались представители администраций, искали варианты разрешения конфликтного противоречия. Единый коммуникационный порыв региональных властей позволяет предположить поступление «задачи» от федерального Центра на начало переговоров и успокоение протестующих. Итогом переговоров с федеральными властями стала временная уступка: снижение стоимости за один км. с 3,73 руб. до 1,53 руб. до апреля 2017 г. (с апреля 2017 г. тариф составил 1,9 руб./км.).

Летом 2016 года около 50 фермеров Краснодарского края попытались организовать тракторный пробег до Москвы с целью информирования Президента России В. Путина о незаконных захватах крупными агрохолдингами региона их урожая и земли. Полиция препятствовала движению автоколонны, а представи-

23 Трудовые протесты в первой половине 2018 г., Центр соииально-трудовых прав, http:// trudprava.ru/expert/analytics/protestanalyt/2068, 09.11.2018 г.

24 Так как в рамках одной протестной акции могло использоваться несколько форм (как правило, две формы), то сумма всех форм превышает $100 \%$.

25 А. Очкина, Социальный протест в современной России: факторы и тенденции развития, „Экономика и управление: научно-практический журнал”, 2016, № 4, с. 69, 73, 75. 
тели региональной власти вынудили протестующих вернуться и начать переговоры с губернатором края ${ }^{26}$.

Опыт крупных протестных действий третьего этапа демонстрирует патриархальный подход протестующих к коллективному действию и отсутствие ясного алгоритма действий власти в отношении протеста. Участники протестных действий подчеркивали свою лояльность Президенту России В. Путину, просили у него защиты своих узкокорпоративных интересов, что ограничивало их возможности в мобилизации сторонников и снижало моральную поддержку наблюдающих граждан. Региональные власти приглашали к диалогу организаторов действия, навязывая компромисс, в то время как правоохранительные органы препятствовали проведению акций, пользуясь законными основаниями.

Четвертый этап протестного действия характеризуется нарастанием социальной напряженности с одновременным увеличением количества протестных акций как локального, так и федерального уровня. С политическими требованиями в 2017-2018 годах выступало общероссийское движение Алексея Навального: 26 марта и 12 июня 2017 г. прошли акции с требованием к власти отреагировать на обвинения в коррупции премьер-министра Дмитрия Медведева. Особенностью протеста 12 июня стало проведение акции в несогласованном месте в Москве, что привело к массовым задержаниям. Во второй половине 2017 г. региональные штабы Навального проводили локальные акции по поддержке выдвижения своего лидера кандидатом в Президенты России. Большинство локальных акций проводилось в рамках действующего законодательства, существующих политических возможностей. В тоже время, по данным Московской Хельсинской группы, в 2017 г. наблюдался рост количества несогласованных радикальных протестных акций ${ }^{27}$.

После отказа ЦИК зарегистрировать Алексея Навального кандидатом в президенты России, его движение готовило наблюдателей на выборах и призвало своих сторонников бойкотировать голосование. Протестная акция «Он нам не царь» 5 мая 2018 г., приуроченная к инаугурации Владимира Путина, прошла в большинстве городов с нарушениями действующего законодательства, что привело, по неофициальным данным, к задержаниям более 1000 участников ${ }^{28}$.

В это же время в стране зафиксирована нисходящая динамика трудовых протестов: 419 - в 2016 г., 334 - в 2017 г., 122 - за 6 мес. 2018 г. Замечено, что уменьшение числа трудовых протестов в 2017-2018 годах происходит за счет снижения протестной активности населения периферийных территорий (про-

26 Акиия протеста кубанских фермеров в Ростове признана незаконной, „Коммерсант”, 23.08.2016, https://www.kommersant.ru/doc/3071009, 02.11.2018.

27 Е. Трифонова, Власти РФ криминализируют протест, „Независимая газета”, 16.10.2017, http://www.ng.ru/politics/2017-10-16/1_7095_protest.html, 20.10.2017.

28 А. Литой, Акции против «царя»: избитые, задержанные, несовершеннолетние, ОВД - Инфо, 08.05.2018, https://ovdinfo.org/articles/2018/05/08/akcii-protiv-carya-izbitye-zaderzhannyenesovershennoletnie, 10.05.2018. 
винциальных городов и сельских территорий), в то время как протестность мегаполисов и городов-миллионников - величина более или менее постоянная ${ }^{29}$. В сравнении с 2016 г., в 2017 г. зафиксировано общее снижение количества публичных мероприятий, проведенных на территории Российской Федерации. По подсчетам Уполномоченного по правам человека в РФ в 2017 г. проведено 47,1 тыс. различных публичных мероприятий, в которых участвовало около 12 млн человек ${ }^{30}$.

Объявление о подготовке пенсионной реформы в июне 2018 г. резко увеличило количество протестов: с 543 в I квартале 2018 г. до 1244 - в III квартале 2018 года ${ }^{31}$. Резкий рост числа протестных акций с конца июля 2018 г. связан с действиями Коммунистической партии РФ (КПРФ), организующей противников правительственного варианта пенсионной реформы. Результатом акций должен был стать запуск процедуры референдума по этому вопросу. Центральная избирательная комиссия России дважды отказала КПРФ в проведении референдума: из-за несоответствия закону формулировки вопроса (в конце июля) ${ }^{32}$, из-за невыполнения всеми пятью зарегистрированными инициативными группами требования регистрации 43 региональных групп (в середине октября) $)^{33}$. Публичные разъяснения президента В. Путина о необходимости реформы и смягчение некоторых её параметров (29 августа) снизили протестный потенциал коллективного действия по этой теме, одновременно снижая его рейтинг доверия.

Резонансными стали протестные акции весной 2018 г. в Волоколамске и Кемерово. Жители подмосковного городка Волоколамск многократно требовали закрытия мусорной свалки «Ядрово» и отставки губернатора Московской области Андрея Воробьева (губернатор с 2013 года). 10 марта жители Волоколамска направили свою просьбу президенту Владимиру Путину. Многотысячные акции протеста и препятствование проезду мусоровозам начались 21 марта, когда 57 детей местной школы были доставлены в больницу с подозрением отравления свалочным газом. В июне 2017 года Владимир Путин «закрыл» мусорный полигон «Кучино» в подмосковной Балашихе, о котором он узнал в ходе прямой

29 Трудовые протесты в первой половине 2018 г., Центр социально-трудовых прав, http:// trudprava.ru/expert/analytics/protestanalyt/2068, 09.11.2018 г.

30 Доклад о деятельности Уполномоченного по правам человека в Российской Федерации за 2017 год, „Российская газета”, 17.04.2018, https://rg.ru/2018/04/16/doklad-site-dok.html, 19.04.2018.

31 Рост протестной активности в России: результаты всероссийского мониторинга 2017-2018 г2., Центр экономических и политических реформ, http://cepr.su/2018/11/08/ protests-2017-2018/, 11.11.2018 г.

32 ЦИК объяснил отказ в реберендуме, РИА-Новости, 27.07.2018, https://ria.ru/society/20180727 /1525496602.html, 02.11.2018

33 Что заменит референдум по пенсионному возрасту, „Ведомости”, 19.10.2018, https://www. vedomosti.ru/opinion/articles/2018/10/19/784083-chto-zamenit-referendum-po-pensionnomu, 1.11.2018. 
линии с гражданами. Протест в Волоколамске стал поводом для особого контроля главы государства этой экологической проблемы.

Пожар в кинотеатре г. Кемерово в марте 2018 года, в котором погиб 41 ребенок, спровоцировал спонтанный многочасовой митинг горожан. Протестующие требовали правдивой информации о трагедии, наказания виновных и отставки губернатора Амана Тулеева (губернатор Кемеровской области в 1997-2018 годах $)^{34}$. Власти заявили о дезинформации со стороны интернет-пользователей (которые сообщили о сотнях погибших), оказали материальную помощь семьям пострадавших и отправили в отставку Тулеева.

В июле 2019 г. в Москве состоялся согласованный митинг в поддержку незарегистрированных кандидатов, желающих принять участие в выборах Московскую городскую Думу. Акция собрала от 12 до 22 тыс. участников, однако городская избирательная комиссия не изменила своего решения.

В целом, протестные акции в России носили локальный, а не массовый, общероссийский характер, требуя от властей решения своих конкретных неполитических проблем. Акции вокруг федеральных тем (выступления дальнобойщиков, акции штабов Навального, противников пенсионной реформы) носили разовый характер, не стали триггером региональных и межрегиональных коллективных действий. Рост числа акций не сопровождался серьезным ростом самоорганизации граждан, а сами акции не попадали в зону внимания федеральных СМИ ${ }^{35}$.

\section{Динамика социальной напряженности и протестного потенциала}

Основным индикатором, которым традиционно пользовались социологи для анализа и прогноза протестного действия является динамика уровня социально-экономической и политической напряженности в регионах. Эксперты Комитета гражданских инициатив в 2015-2017 годах осуществляли мониторинг экономических, политических и протестных показателей. В целом, в регионах в рассматриваемый период установилась относительно спокойная социально-экономическая ситуация, которая, впрочем, не снижает рисков протестных выступлений в среднесрочной перспективе. Исследователи уверены, что экономические проблемы не являются основными причинами протестного поведения и действия. Авторы доклада зафиксировали во втором полугодии 2017 года спад публичной протестной активности по сравнению с пиковыми показателями первой половины 2017 г. и возвращение этого показателя к фоновому уровню 2015-2016 годов ${ }^{36}$.

34 Кемеровские власти десять часов отчитьвались перед протестующими, LENTA.RU, 27.03.2018, https://lenta.ru/news/2018/03/27/protest_ends/, 10.11.2018.

35 Общественные волнения в регионах России и пути их урегулирования (2016 - первая половина 2017 годов), Фонд «Петербургская политика», https://fpp.spb.ru/fpp-russian-public-unrest-2016-2017, 10.10.2017.

36 Эксперты КГИ представили итоги мониторинга социально-экономической и политической напряженности регионов за три года, Комитет гражданских инициатив, 20.06.2018, https:// komitetgi.ru/analytics/3797/, 01.07.2018. 
Другим «классическим» индикатором протестных настроений и потенциального действия является динамика ожидания протестов и уровня декларируемой личной готовности к протесту. По данным ВЦИОМ наивысшие точки ожидания респондентами акций протеста по рассчитанному индексу были в 2005 году (49 пунктов), 3 квартале 2017 г. (43 пункта) и в конце июля 2018 г. (43 пункта). В 2019-2020 гг. индекс колебался в пределах 32-39. Индекс личной декларируемой готовности принять участие в протестах достигал пиковых значений в 2005 году (37 пунктов), в 2011 г. (36 пунктов), первом квартале 2016 года (34 пункта) и в конце июля 2018 года (37 пунктов). С августа 2019 г. индекс не поднимается выше $31^{37}$. Другими словами, начало обсуждения пенсионной реформы подняло уровень ожидания и готовности протестов до показателей 2005 года, периода массовых протестов против монетизации льгот, однако объяснения президента В. Путина снизили готовность к публичному протесту.

Результаты исследований последних двух лет конкурирующего социологического центра демонстрировали нежелание большинства россиян принимать участие в акциях протеста в защиту своих прав в связи с падением уровня жизни или с политическими требованиями. По данным Левада-Центра, такого мнения придерживалось более $80 \%$ респондентов осенью 2017 года ${ }^{38}$ и $88 \%$ в марте 2018 года ${ }^{39}$. Начало обсуждения пенсионной реформы в июне-июле 2018 года повысило ожидание протестов по экономическим требованиям с 17\% (март) до $41 \%$ (июль), а субъективная готовность принять в них участие с $8 \%$ до $28 \%$ за тот же период ${ }^{40}$.

Ещё в 2017 году российские социологи фиксировали противоречивое общественное отношение к переменам: с одной стороны - запрос «на застой» ${ }^{41}$, о одновременной надеждой «на перемены» ${ }^{42}$. После богатого на революции XX века современные россияне в целом стали относиться к радикальным политическим переменам с опаской, как к катаклизмам. В обществе не ощущалось потребности в переменах, ни экономических, ни политических. Число россиян, ориентированных на статус-кво, за последние пять лет выросло с 58\% в 2011 до 71\% в 2016

37 Протестный потенцииал, Всероссийский центр изучения общественного мнения, https:// wciom.ru/news/ratings/protestnyj_potencial/, 01.03.2020.

38 Россияне не верят в протесты, Левада-центр, 28.09.2017, https://www.levada.ru/2017/09/28/ rossiyane-ne-veryat-v-protesty/, 10.10.2017.

39 Протестный потенциал, Левада-Центр, 16.04.2018, https://www.levada.ru/2018/04/16/protestnyj-potentsial-7/, 16.04.2018.

40 Потенциал протеста, Левада-Центр, https://www.levada.ru/indikatory/polozhenie-del-vstrane/, 15.11.2018.

41 Ю. Латов, Протестные настроения в протестные действия россиян, „Социологическая наука и социальная практика", 2017, № 1, с. 51.

42 Д. Волков, А. Колесников, Мы ждем перемен. Есть ли в России массовый спрос на изменения?, Московский Центр Карнеги, декабрь 2017, с. 5. 
году ${ }^{43}$. Сейчас у россиян очень осторожные ожидания, «лишь бы не было хуже», «как бы не было войны» и т. д. Поэтому если в 2011-2012 был выраженный запрос на перемены, то в 2017 году выраженный запрос на стабильность ${ }^{44}$.

«Ориентация на стабильность, однако, вовсе не тождественна согласию общества на застой и деградацию. Россияне боятся вовсе не перемен, а дестабилизации ситуации в стране, радикальной ломки привычных устоев жизни» ${ }^{45}$. При этом подавляющая часть носителей спроса «на застой» сохраняют критический взгляд, фиксируют недостатки сегодняшнего дня. Однако у общества нет ни сил активно «желать перемен», ни понимания, каких именно перемен надо желать (кроме, разве, самых общих идей о снижении дифференциации доходов и борьбы с коррупцией), ни авторитетных организованных сообществ, готовых политически возглавить протест.

По наблюдениям Дениса Волкова и Андрея Колесникова, спрос на радикальный тип перемен все же есть. Аналитики Карнеги-центра по итогам своего исследования в августе 2017 г. разделили сторонников перемен на две равные группы: $42 \%$ россиян выступают за решительные и полномасштабные перемены, еще $41 \%$ считает, что нужны незначительные изменения и постепенное улучшение текущей ситуации. И лишь немногим более 10 \% хотели бы оставить все, как есть, ничего не меняя ${ }^{46}$. Наблюдения протестных действий жителей Московской области в 2016 г. показали, с одной стороны, активизацию местных сообществ и местной проблематики, а с другой - патерналистский настрой участников гражданского протеста, проявляющийся в апелляции к власти, в стремлении использовать существующие политические институты и возможности, а не создавать новые ${ }^{47}$.

Как считает Александр Кинсбурский, усиление массового недовольства социально-экономическими условиями жизни и запрос «на перемены» не ведет автоматически к росту социальной напряжённости и массовым акциям протеста. В России наблюдается снижение потенциала протеста в силу определённого разочарования в эффективности протестных действий как способа разрешения политических и экономических проблем, а также по причине ужесточения правил проведения массовых политических мероприятий и усиления ответствен-

43 В. Петухов, Кризисная реальность и возможность политической трансформации российского общества, „Политические исследования”, 2016, № 5, с. 12.

44 В. Федоров, Будущее повернулось к нам своей темной стороной, „Ведомости”, 29.08.2016, http:// www.vedomosti.ru/politics/characters/2016/08/29/654769-buduschee-povernulos, 02.09.2016.

45 В. Петухов, Демократизация российского общества: возможна ли вторая попытка?, „Политические исследования", 2017, № 5, с. 8-23.

46 Д. Волков, А. Колесников, Мыждем перемен. Есть ли в России массовый спрос на изменения?, Московский Центр Карнеги, декабрь 2017, с. 6.

47 Д. Волков, А. Колесников, Самоорганизация гражданского общества в Москве. Мотивь, возможности и пределы политизации, Рабочие материалы Московского Центра Карнеги, декабрь 2016, с. 1-2, 6-7, 13. 
ности за их нарушение ${ }^{48}$. По наблюдениям директора Левада-Центра Льва Гудкова, «недовольство достигло определенного уровня и дальше, скорее всего, не будет расти, потому что люди не видят возможности, как это выразить. Они не верят, что на власти можно оказывать какое-то давление» ${ }^{49}$.

Результаты последних качественных исследований фиксируют глубинные перемены в общественных настроениях в отношении к возможностям протеста и личного участия. Эксперты Комитета гражданских инициатив к середине 2018 года наблюдают высокую готовность респондентов к переменам, стремление рассчитывать на собственные силы, резко возросшей готовности к риску, а также тенденцию отчуждения от власти и интеграции с себе подобными ${ }^{50}$.

\section{Изменение политико-правовых возможностей для протеста}

На протяжении 2010-х годов правовые возможности для легальной публичной демонстрации своего несогласия в России были несколько ограничены. Сокращение возможностей для протестного действия связано не с запретами и ограничением, а с ужесточением правоприменительной практики.

Конституция Российской Федерации дает широкие возможности для публичного действия. Статья 31 Основного закона закрепляет право граждан Российской Федерации собираться мирно, без оружия, проводить собрания, митинги и демонстрации, шествия и пикетирование (ст. 31), при этом каждому гарантируется свобода мысли и слова и никто не может быть принужден к выражению своих мнений и убеждений или отказу от них (ст. 29). Конституция РФ устанавливает, что данные права не относятся к числу конституционных прав и свобод, которые не подлежат ограничению (ст. 56) и могут быть ограничены федеральным законом в той мере, в какой это необходимо в целях защиты основ конституционного строя, нравственности, здоровья, прав и законных интересов других лиц, обеспечения обороны страны и безопасности государства (ст. 55) 51 .

Большинство вопросов подготовки и проведения публичных мероприятий регламентируется Федеральным законом РФ от 19.06.2004 № 54-Ф3 «О собраниях, митингах, демонстрациях, шествиях и пикетированиях». Согласно статье 2 названного закона публичное мероприятие - это открытая, мирная, доступная

48 А. Кинсбурский, М. Топалов, Социальная напряженность и массовые акции протеста (к вопросу о механизме действия), „Социологическая наука и социальная практика”, 2016, № 1, c. 31 .

49 Лев Гудков: В Кремле рассуждают, что россияне потерпят, побрюзжат и смирятся, Daily Storm, https://dailystorm.ru/vlast/lev-gudkov-v-kremle-rassuzhdayut-chto-rossiyane-poterpyatpobryuzzhat-i-smiryatsya, 03.11.2018.

50 М. Дмитриев, С. Белановский, А. Никольская, Признаки изменения общественных настроений и их возможные постедствия, Комитет гражданских инициатив, 11.10.2018, С. 14-15, 23, https://komitetgi.ru/news/news/3902/, 12.11.2018.

51 Конституиия Российской Федерации. Принята всенародным голосованием 12 декабря 1993 года, http://www.constitution.ru, 12.11.2018. 
каждому акция, осуществляемая по инициативе граждан, политических партий, других общественных и религиозных объединений. Целью публичного мероприятия является свободное выражение и формирование мнений, выдвижение требований по различным вопросам политической, экономической, социальной и культурной жизни страны и вопросам внешней политики. Целью публичного мероприятия может быть информирование избирателей о своей деятельности при встрече депутата законодательного органа государственной власти, депутата представительного органа муниципального образования с избирателями ${ }^{52}$.

Федеральный закон выделяет пять видов публичных мероприятий:

- собрание - совместное присутствие граждан в специально отведенном или приспособленном для этого месте для коллективного обсуждения каких-либо общественно значимых вопросов;

- митинг - массовое присутствие граждан в определенном месте для публичного выражения общественного мнения по поводу актуальных проблем преимущественно общественно-политического характера;

- демонстрация - организованное публичное выражение общественных настроений группой граждан с использованием во время передвижения, в том числе на транспортных средствах, плакатов, транспарантов и иных средств наглядной агитации;

- шествие - массовое прохождение граждан по заранее определенному маршруту в целях привлечения внимания к каким-либо проблемам;

- пикетирование - форма публичного выражения мнений, осуществляемого без передвижения и использования звукоусиливающих технических средств путем размещения у пикетируемого объекта одного или более граждан, использующих плакаты, транспаранты и иные средства наглядной агитации, а также быстровозводимые сборно-разборные конструкции ${ }^{53}$.

Правоприменительная практика показала стремление муниципальных властей не согласовывать (ограничивать) проведение протестных акций. В 2017 г. к Уполномоченному по правам человека в РФ поступило 51 обращение от граждан с жалобами на нарушение права на свободу собраний, из них 39\% касались немотивированных отказов в проведении публичного мероприятия, которые заявители получали накануне проведения акции или вообще не получали ответов. В ряде жалоб был поднят вопрос о привлечении к административной ответственности за организацию или участие в публичных мероприятиях, проводимых с нарушением установленного порядка. Заявители указывали на несогласие с судебными решениями, основанными исключительно на документах, пред-

\footnotetext{
52 Ст. 2, Федеральный закон «О собраниях, митингах, демонстрациях, шествиях и пикетированиях» от 19.06.2004 № 54-Ф3, Правовая система «КонсультантПлюс», http://www.consultant. $\mathrm{ru} /$ document/cons_doc_LAW_48103/, 14.11.2018.

53 Ibidem.
} 
ставленных полицией, при игнорировании доказательств стороны защиты; на «конвейерный» характер судебных заседаний; на чрезмерно строгие наказания за формальные нарушения правил проведения публичных акций, на игнорирование судами смягчающих обстоятельств и др. ${ }^{54}$.

В соответствии с постановлением Верховного Суда РФ органы исполнительной власти субъектов РФ или органы местного самоуправления власти (далее - органы публичной власти) должны создавать возможности для использования гражданами своего права на публичные мероприятия. Утвержденный уведомительный порядок проведения публичных мероприятий, позволяет органам власти принять разумные и необходимые меры для реализации конституционного права граждан на проведение публичного мероприятия в условиях, обеспечивающих соблюдение интересов государственной и общественной безопасности, общественного порядка, охраны здоровья и нравственности населения и защиты прав и свобод других лиц. К примеру, неудобства, связанные с необходимостью временного изменения маршрутов движения транспорта, помехи движению пешеходов не могут расцениваться в качестве уважительной причины предложения об изменении места и (или) времени проведения публичного мероприятия, если условия дорожного движения и поведение всех участников этого движения будут находиться в пределах допустимых норм и не будут способствовать возникновению дорожно-транспортных происшествий ${ }^{55}$.

В целях осуществления права на проведение публичного мероприятия закреплена возможность проведения согласительных процедур между организаторами публичных мероприятий и органами власти, направленных на определение места, времени, формы и иных условий проведения публичных мероприятий, отвечающих достижению законной цели планируемого публичного мероприятия и соблюдению интересов иных лиц, обеспечению общественного порядка и безопасности. Конституционный суд РФ считает, что не является отказом в согласовании проведения публичного мероприятия направление органом публичной власти в адрес организатора публичного мероприятия обоснованного предложения об изменении места и (или) времени проведения публичного мероприятия, а также предложения об устранении несоответствия указанных в уведомлении целей, форм и иных условий проведения публичного мероприятия требованиям Федерального закона № 54 .

Как было указано выше, организаторов публичных мероприятий часто привлекали к административной ответственности за несоблюдения правил их проведения. Наиболее распространенным «нарушением» стало превышение ре-

54 Доклад о деятельности Уполномоченного по правам человека в Российской Федерации за 2017 год, „Российская газета”, 17.04.2018, https://rg.ru/2018/04/16/doklad-site-dok.html,19.04.2018.

55 Постановление Пленума Верховного Суда РФ от 26 июня 2018 г. № 28 «О некоторых вопросах, возникающих у судов при рассмотрении административных дел и дел об административных правонарушениях, связанных с применением законодательства о публичных мероприятиях», http://www.supcourt.ru/documents/own/26969/, 30.02.2018. 
ального числа участников акции к заявленной в уведомлении. В связи с этим Верховный Суд РФ указал, что «привлечение организатора публичного мероприятия к административной ответственности по данной норме в связи с превышением предельной заполняемости (вместимости) территории (помещения), на которой проводится публичное мероприятие, возможно лишь в том случае, когда такое превышение сопряжено с созданием угрозы общественной безопасности и правопорядку и было обусловлено действиями (бездействием) организатора публичного мероприятия. Например, организатор публичного мероприятия, допустив превышение количества его участников, не принял направленные на ограничение доступа граждан к участию в публичном мероприятии меры, которые он мог и обязан был принять» ${ }^{56}$.

С начала 2018 г. в масс-медиа озвучиваются предложения по корректировке законодательства о проведении публичных мероприятий в сторону ограничения возможностей их проведения. Известный российский журналист В. Соловьев в своем выступлении в Совете Федерации 28 марта 2018 г. предложил изменить законодательство, регламентирующее проведение публичных мероприятий, в сторону повышения эффективности обеспечения безопасности участников коллективных акций ${ }^{57}$. По мнению Уполномоченного по правам человека в РФ, «необходимо разработать дополнительный механизм и инструментарий для того, чтобы предупредить участие несовершеннолетних в массовых акциях протеста, тем более стихийно организованных. В связи с этим заслуживает внимания предложение ... о введении законодательного запрета на вовлечение школьников в акции протеста, особенно несанкционированные» ${ }^{58}$. В ноябре 2018 г. данный законопроект был принят Государственной Думой в первом чтении ${ }^{59}$.

В целом, в России сформирована нормативно-правовая база, создающая возможности для организации и проведения публичных коллективных и индивидуальных действий. В 2017-2018 годах правоохранительные и судебные органы России регулярно выносили решения об административных правонарушениях организаторам публичных акций, что вынудило последних обратиться в Конституционный Суд РФ. В СМИ обсуждаются проекты законодательного ограничения права граждан на проведение публичных (в том числе - протестных) действий.

56 Постановление Пленума Верховного Суда РФ от 26 июня 2018 г. № 28 «О некоторых вопросах, возникающих у судов при рассмотрении административных дел и дел об административных правонарушениях, связанных с применением законодательства о публичных мероприятиях», http://www.supcourt.ru/documents/own/26969/, 30.02.2018.

57 В Совете Федерации в рамках «времени эксперта» выступил российский журналист В. Соповьев 28.03.2018, http://www.council.gov.ru/events/news/90876/, 30.03.2018.

58 Доклад о деятельности Уполномоченного по правам человека в Российской Федерации за 2017 год, „Российская газета”, 17.04.2018, https://rg.ru/2018/04/16/doklad-site-dok.html,19.04.2018.

59 Законопроект № 462244-7, http://sozd.duma.gov.ru/bill/462244-7, 15.11.2018. 


\section{Выводы}

Накануне столетнего юбилея русской революции и в течение всего 2017 г. экспертное сообщество в России фиксировало рост числа протестных акций как согласованных, так и не согласованных. Значимым фактором общероссийской мобилизации недовольных властью жителей крупных городов стала общественно-политическая активность Алексея Навального, сумевшего в течение 2017 г. создать широкую сеть региональных организаций и провести всероссийские протестные акции с политическими требованиями. Все это создавало впечатление радикальных перемен в общественном сознании, перехода россиян от состояния «агрессивной неподвижности» ${ }^{60}$ к активным формам коллективной демонстрации недовольства властью. Как заметил политолог Борис Кагарлицкий: «Сначала казалось, будто границы возможного очень жестко очерчены. Но вдруг обнаруживается, что эти границы существовали лишь в сознании людей... Все начинают тестировать границы. Возникает ощущение, что теперь возможно все» ${ }^{61}$.

В рассматриваемый период 2008-2019 годов общественный протест в России носил локальный, не массовый характер, возникал по конкретным проблемам местных сообществ и проходил в форме митингов или шествий. Доминирующей стратегией протестующих было неконфликтное обращение к вышестоящим властям с просьбой оказать влияние на нижестоящие власти и разрешить сложившуюся проблемную ситуацию. По наблюдениям социологов, в общественном сознании преобладает настроение отказа от активных протестных действий как в силу разочарования в таком средстве коммуникации с властью, так и по причине ужесточения правил проведения массовых мероприятий и усиления ответственности за их нарушение. Одновременно зафиксировано снижение уровня доверия к федеральной власти.

Политическая проблематика не находила массовой поддержки граждан. Общероссийские политические акции протеста А. Навального собирали заметные несогласованные протестные акции в крупных городах, которые часто заканчивались задержаниями участников. Отказ в регистрации Алексея Навального кандидатом в Президенты на выборах лишил его возможности выйти за пределы уличной (митинговой) активности и заняться борьбой за позиции в органах власти, стать полноценным субъектом политической оппозиции. Сокращение возможностей лидера и административные ограничения снижают готовность симпатизантов Навального участвовать в публичных протестных акциях.

Социальный протест стал неотъемлемой частью российского общества, частью повседневной жизни россиян. С 2019 года декларируемая готовность граждан к протесту приняла фоновый уровень, а эксперты фиксируют средне-

60 С. Грин, Природа неподвижности российского общества, Pro et Contra, январь-апрель 2011, c. 6-19.

61 Б. Кагарлицкий, Между классом и дискурсом. Левые интеллектуалы на страже капитализма, Москва, 2017, с. 142. 
Pobrane z czasopisma Wschód Europy http://journals.umcs.pl/we

Data: 26/04/2023 06:14:02

срочные факторы накопления социально-экономической и политической напряженности. По наблюдениям политологов и юристов, произошло ужесточение правил проведения публичных мероприятий и наказаний за их нарушения в период 2012-2019 гг. в результате роста протестной активности. Реализация рестриктных норм и практик властью снизили готовность россиян к участию в протестных действиях. В условиях сужения возможностей для легального публичного протестного действия, возможно ожидать перехода протеста в непубличные формы. Тем более, что в общественном сознании произошли перемены, благоприятствующие поддержке протестного действия.

\begin{abstract}
Аннотация: Статья посвящена определению этапов протестного действия в России 2008-2018 годов, анализу динамики количества и формы протестных акций; оценке общероссийского уровня социальной напряженности и протестного потенциала граждан, а также анализу политико-правовых возможностей и ограничений протестного действия в этот период. По нашим наблюдениям рост протестной активности россиян привел к ужесточению правил проведения публичных мероприятий, а применение санкций к нарушителям этих норм - снизил готовность к участию в протестах.
\end{abstract}

Ключевые слова: протест, политический протест, коллективное действие, политические возможности

\title{
Zachowanie i działania protestacyjne we współczesnej Rosji: możliwości i ograniczenia
}

Streszczenie: W artykule scharakteryzowano etapy akcji protestacyjnych w Rosji w latach 2008-2018 pod kątem dynamiki, liczby i form akcji protestacyjnych. Wzięto też pod uwagę ocenę ogólnorosyjskiego poziomu napięcia społecznego i potencjału protestacyjnego obywateli, a także analizę politycznych i prawnych możliwości oraz ograniczeń działań protestacyjnych w tym okresie. Zgodnie z naszymi spostrzeżeniami wzrost aktywności protestacyjnej Rosjan doprowadził do zaostrzenia zasad organizacji wydarzeń publicznych, a zastosowanie sankcji wobec osób naruszających te normy zmniejszyło chęć uczestnictwa w protestach.

Słowa kluczowe: protest, protest polityczny, akcja zbiorowa, możliwość polityczna

\section{Protesting behavior and action in contemporary Russia: opportunities and limitations}

Abstract: The article is devoted to determining the stages of protest action in Russia in 2008-2018, analyzing the dynamics of the number and form of protest actions; assessment of the all-Russian level of social tension and protest potential of citizens, as well as analysis of political and legal opportunities and limitations of protest action during this period. According to our observations, an increase in the protest activity of Russians has led to stricter rules for holding public events, and the application of sanctions against violators of these norms has reduced the willingness to participate in protests.

Keywords: protest, political protest, collective action, political opportunity 
Pobrane z czasopisma Wschód Europy http://journals.umcs.pl/we

Data: 26/04/2023 06:14:02

Протестное поведение и действие в современной России: возможности и ограничения

\section{Источники и литература}

\section{Документы и правовые акты:}

Doklad o sostoyanii grazhdanskogo obshchestva v Rossii (2011 g.), Moskva, 2012.

Federal'nyy zakon № 54-FZ ot 19.06.2004 «0 sobraniyakh, mitingakh, demonstratsiyakh, shestviyakh i piketirovaniyakh», http://www.consultant.ru/document/cons_doc_LAW_48103/

Konstitutsiya Rossiyskoy Federatsii. Prinyata vsenarodnym golosovaniyem 12.12 .1993 g., http://www. constitution.ru

Postanovleniye Plenuma Verkhovnogo Suda RF ot 26 iyunya 2018 g. № 28 «0 nekotorykh voprosakh, voznikayushchikh u sudov pri rassmotrenii administrativnykh del i del ob administrativnykh pravonarusheniyakh, svyazannykh s primeneniyem zakonodatel'stva o publichnykh meropriyatiyakh», http://www.supcourt.ru/documents/own/26969/

\section{Монографии:}

Graeme R., The Politics of Protest in Hybrid Regimes. Managing Dissent in Post-Communist Russia, Cambridge University Press, 2011.

Greene S., Moscow in Movement: Power and Opposition in Putin's Russia, Stanford University Press, 2014.

Kagarlitskiy B., Mezhdu klassom i diskursom. Levyye intellektualy na strazhe kapitalizma, Moskva, 2017. Koen D., Arato E., Grazhdanskoye obshchestvo i politicheskaya teoriya, Moskva, 2003.

Shevtsova L., My: zhizn'v epokhu bezvremen'ya, Moskva, 2014.

Tarrow S., Power in Movement. Social Movement and Contentious Politics, Cambridge University Press, 2011.

Yavlinskiy G., Periferiynyy avtoritarizm. Kak i kuda prishla Rossiya, Moskva, 2015.

Zdravomyslova E., Paradigmy zapadnoy sotsiologii obshchestvennykh dvizheniy, Sankt-Peterburg, 1993.

\section{Периодические издания:}

Bizyukov P., Dinamika trudovykh protestov v Rossii (2008-2011), „Vestnik obshchestvennogo mneniya”, 2011, № 2.

Grin S., Priroda nepodvizhnosti rossiyskogo obshchestva, „Pro et Contra”, yanvar'-aprel' 2011.

Kinsburskiy A., Topalov M., Sotsial'naya napryazhennost' i massovyye aktsii protesta (k voprosu o mekhanizme deystviya), „Sotsiologicheskaya nauka i sotsial'naya praktika”, 2016, № 1.

Kostyushev V., Sotsial'nyy protest v pole politiki: potentsial, repertuar, diskurs (opyt teoreticheskoy interpretatsii i empiricheskoy verifikatsii), „Politicheskiye issledovaniya”, 2011, № 4.

Latov Yu., Prizrak «revolyutsionnoy situatsii»: protestnyye deystviya i protestnyye nastroyeniya sovremennykh rossiyan, „Obshchestvennyye nauki i sovremennost”', 2017, № 2.

Latov Yu., Protestnyye nastroyeniya v protestnyye deystviya rossiyan, „Sotsiologicheskaya nauka i sotsial'naya praktika", 2017, № 1.

Lobanova 0., Ot obyvateley k aktivistam - i obratno. Obzor protestnykh issledovaniy v Rossii 1991-2015 godov, „Neprikosnovennyy zapas. Debaty o politike i kul'ture”, 2015, № 5.

Ochkina A., Sotsial'nyy protest v sovremennoy Rossii: faktory i tendentsii razvitiya, „Ekonomika i upravleniye: nauchno-prakticheskiy zhurnal", 2016, № 4. 
Petukhov V., Demokratizatsiya rossiyskogo obshchestva: vozmozhna li vtoraya popytka?, „Politicheskiye issledovaniya", 2017, № 5.

Petukhov V., Krizisnaya real'nost' i vozmozhnost' politicheskoy transformatsii rossiyskogo obshchestva, „Politicheskiye issledovaniya”, 2016, № 5.

Shkel' S., Sabitov M., Massovyy politicheskiy protest v sovremennoy Rossii: dinamika i spetsifika razvitiya, „Pravo i polityka”, № 10, 2012.

Ushkin S., Na puti k luchshemu obshchestvu, ili pochemu lyudi stanovyatsya aktivistami?, „Monitoring obshchestvennogo mneniya", 2016, № 4.

Volkov D., Kolesnikov A., My zhdem peremen. Est' li v Rossii massovyy spros na izmeneniya?, Moskovskiy Tsentr Karnegi, dekabr' 2017.

Volkov D., Kolesnikov A., Samoorganizatsiya grazhdanskogo obshchestva v Moskve. Motivy, vozmozhnosti i predely politizatsii, Rabochiye materialy Moskovskogo Tsentra Karnegi, dekabr' 2016.

Volkov D., Protestnyye mitingi v Rossii kontsa 2017 - nachala 2012 gg.: zapros na demokratizatsiyu politicheskikh institutov, „Vestnik obshchestvennogo mneniya”, 2012, № 2.

\section{Интернет источники:}

Aktsiya protesta kubanskikh fermerov v Rostove priznana nezakonnoy, „Kommersant”, 23.08.2016, https://www.kommersant.ru/doc/3071009

Dmitriyev M., Belanovskiy S., Nikol'skaya A., Priznaki izmeneniya obshchestvennykh nastroyeniy i ikh vozmozhnyye posledstviya, Komitet grazhdanskikh initsiativ, 11.10.2018, https://komitetgi.ru/news/ news/3902/

Doklad o deyatel'nosti Upolnomochennogo po pravam cheloveka v Rossiyskoy Federatsii za 2017 god, "Rossiyskaya gazeta", 17.04.2018, https://rg.ru/2018/04/16/doklad-site-dok.html

God sanktsiy i deshevoy nefti: protestnaya situatsiya, Tsentr ekonomicheskikh i politicheskikh reform, http://cepr.su/wp-content/uploads/2015/11/Год-санкций-и-дешевой-нефти_протестнаяситуация1.pdf

Gudkov L., V Kremle rassuzhdayut, chto rossiyane poterpyat, pobryuzzhat i smiryatsya, Daily Storm, https://dailystorm.ru/vlast/lev-gudkov-v-kremle-rassuzhdayut-chto-rossiyane-poterpyatpobryuzzhat-i-smiryatsya

V Sovete Federatsii v ramkakh «vremeni eksperta» vystupil rossiyskiy zhurnalist V. Solov'yev, 28.03.2018, http://www.council.gov.ru/events/news/90876/

Litoy A., Aktsii protiv "tsarya»: izbityye, zaderzhannyye, nesovershennoletniye, OVD - Info, 08.05.2018, https://ovdinfo.org/articles/2018/05/08/akcii-protiv-carya-izbitye-zaderzhannyenesovershennoletnie

Obshchestvennyye volneniya v regionakh Rossii i puti ikh uregulirovaniya (2016 - pervaya polovina 2017 godov), Fond "Peterburgskaya politika", https://fpp.spb.ru/fpp-russian-public-unrest-2016-2017

Protestnyy potentsial, Vserossiyskiy tsentr izucheniya obshchestvennogo mneniya, https://wciom.ru/ news/ratings/protestnyj_potencial/

Razvitiye institutov i nakopleniye kachestva. Rossiyskaya politicheskaya sistema mezhdu federal'nymi vyborami 2011 i 2016 goda, ReThinkingRussia, 2016, http://rethinkingrussia.ru/2015/12/развитиеинститутов-и-накопление-кач/ 
Pobrane z czasopisma Wschód Europy http://journals.umcs.pl/we

Data: 26/04/2023 06:14:02

Rossiya udivlyayet: pyat' epokh v rossiyskom obshchestvennom mnenii (1987-2017). Press-vypusk № 3320, Vserossiyskiy tsentr izucheniya obshchestvennogo mneniya, https://wciom.ru/index. php?id=236\&uid $=116098$

Rossiyane ne veryat v protesty, Levada-tsentr, 28.09.2017, https://www.levada.ru/2017/09/28/rossiyane-ne-veryat-v-protesty/

Rost protestnoy aktivnosti v Rossii: rezul'taty vserossiyskogo monitoringa 2017-2018 gg., Tsentr ekonomicheskikh i politicheskikh reform, http://cepr.su/2018/11/08/protests-2017-2018/

Trifonova E., Vlasti RF kriminaliziruyut protest, "Nezavisimaya gazeta", 16.10.2017, http://www.ng.ru/ politics/2017-10-16/1_7095_protest.html

Trudovyye protesty v pervoy polovine 2018 g., Tsentr sotsial'no-trudovykh prav, http://trudprava.ru/ expert/analytics/protestanalyt/2068

Fedorov V., Budushcheye povernulos' k nam svoyey temnoy storonoy, "Vedomosti" 29.08.2016, http:// www.vedomosti.ru/politics/characters/2016/08/29/654769-buduschee-povernulos

Eksperty KGI predstavili itogi monitoringa sotsial'no-ekonomicheskoy i politicheskoy napryazhennosti regionov za tri goda, Komitet grazhdanskikh initsiativ, 20.06.2018, https://komitetgi.ru/analytics/3797/ 